\title{
poemas de Fabrício Corsaletti
}

não estão mortos

foram para outra cidade

a que não sei como chegar

\section{História}

Na cidade em que nasci

havia um bicho morto em cada sala

mas nunca se falou a respeito

os meninos cavávamos buracos nos quintais

as meninas penteavam bonecas

como em qualquer lugar do mundo

nas salas o bicho morto apodrecia

as tripas cobertas de moscas

(os anos cobertos de culpas)

e ninguém dizia nada

mais tarde bebíamos cerveja

as brincadeiras eram junto com as meninas

a noite aliviava o dia

das janelas o sangue podre

(ninguém tocava no assunto)

escorria lento e seco

e a cidade fedia era já insuportável

parti à noite despedidas de praxe

embora sem dúvidas chorasse 
Dois poemas para minha sombra

1.

minha sombra

sob o sol absurdo

copia o meu ser original

mas o que sabe de mim

na noite intima?

2.

minha sombra

não é a alma que perdi

Onde ela vive não importa

um pequeno sol

como uma moeda

no bolso da camisa

Fabrício Corsaletti é formado em Letras pela FFLCH-USP, publicou Movediço (Labortexto, 2001) e O Sobrevivente (Hedra, 2003). Estudos para o seu Corpo, incluindo os dois anteriores e mais poemas inéditos, será publicado pela Companhia das Letras em 2007. 